\title{
Petrol Fiyatlarn ve Kazakistan Reel Döviz Kuru: ARDL Sınır Testi Yaklaşımı ${ }^{*}$
}

\section{Seymur Ağazade ${ }^{* *}$}

Öz

Bu çalışmada, reel petrol fiyatlarının Kazakistan reel döviz kuru üzerindeki etkisi incelenmiştir. Bu amaçla, reel döviz kuruna ilişkin farklı endeksler ve sınır testi yaklaşımı kullanılmıştır. Uygulanan ARDL yaklaşımının uzun döneme ilişkin sonuçları, reel petrol fiyatlarındaki artı̧ın Kazakistan'ın ticaret yaptı̆̆ tüm ülkeleri kapsayan reel efektif döviz kuru ile BDT dışındaki ülkeleri kapsayan reel efektif döviz kurunun değerlenmesine, fakat BDT ülkelerini kapsayan reel efektif döviz kurunun ise değer kaybetmesine neden olduğunu göstermektedir. Bunun yanı sıra, ARDL hata düzeltme modeli, uzun dönem ilişkide ortaya çıkan bir sapmadan sonra tekrar dengeye dönüşs sürecinin, diğer iki kur göstergesine nispeten, BDT ülkelerini kapsayan reel efektif döviz kuru dikkate alındığında daha kısa sürdüğünü göstermektedir. Çalışma sonuçlarına göre, reel döviz kuru istikrarı için, gelişen petrol ve doğalgaz sektörleri ile birlikte Kazakistan'ın diğer sektörlerde de gelişmeyi sürdürmesi ve özellikle petrol ve doğalgaz bakımından zengin komşu ülkelerle ticaret hacmini artırması önem taşımaktadır.

\section{Anahtar Kelimeler}

Petrol fiyatları, reel döviz kuru, sınır testi, ARDL yaklaşımı, Kazakistan.

Geliş Tarihi: 15 Ocak 2017 - Kabul Tarihi: 26 Haziran 2018

Bu makaleyi şu şekilde kaynak gösterebilirsiniz:

Ağazade, Seymur (2020). "Petrol Fiyatları ve Kazakistan Reel Döviz Kuru: ARDL Sınır Testi Yaklaşımı”. bilig - Türk Dünyası Sosyal Bilimler Dergisi 94: 217-248.

** Prof. Dr., Alanya Alaaddin Keykubat Üniversitesi, Turizm Fakültesi, Turizm İşletmeciliği BölümüAntalya/Türkiye ORCID ID: 0000-0001-5484-5189

seymur.agazade@alanya.edu.tr 


\section{Giriş}

Petrol, Kazakistan ekonomisinde önemli paya sahiptir. Bu ülke, petrol ve diğer minerallere ilişkin kanıtlanmış rezervlerin miktarı bakımından da hayli zengindir. Kazakistan ihracatı önemli derecede petrol ve diğer doğal kaynaklara dayanmaktadır. Bu nedenle, dünya petrol fiyatlarındaki dalgalanmaların Kazakistan ekonomisi açısından önemli sonuçlarının olması beklenir. Petrol fiyatlarındaki dalgalanmaların reel döviz kuru üzerindeki etkisi, Kazakistan gibi petrol ve doğalgaz sektörlerinin yanı sıra, diğer sektörleri de geliştirmeye çalışan ekonomiler için oldukça önemlidir. Petrol fiyatlarındaki artış bir yandan ihracat gelirlerinin artmasına neden olurken, reel döviz kurunun yükselmesi geliştirilmeye çalışlan diğer sektörlerin rekabet gücünü sınırlandırarak gelişimini engellemektedir.

Petrol fiyatlarının reel döviz kuru üzerindeki etkisine yönelik teorik tartışmalarda, petrol fiyatlarındaki değişimlerin başlangıç ve nihai ya da kısa ve uzun dönem etkilerinin farklılaşabileceği ileri sürülmektedir. Uygulamalı çalışmalarda ise, petrol fiyatlarındaki değişmelerin döviz kuru üzerindeki etkisi petrol ithal eden gelişmiş ülkeler açısından ve petrol ihraç eden ülkeler açısından araştırılmıştır. Konuya ilişkin literatürde, Kazakistan çok sınırlı sayıda araştırmada yer almıştır. Petrol ihraç eden bir ülke olmakla birlikte, Kazakistan'ın ithalatında önemli bir paya sahip olan ülke, yine enerji ihracatçısı olan Rusya'dır. Aynı zamanda, Azerbaycan ve Türkmenistan gibi petrol ya da doğal gaz zengini ülkeler de diğer küçük ticari partnerlerdir. Çalışmanın teorik tartışma bölümünde de görüleceği gibi, petrol fiyatlarının döviz kuru üzerindeki etkisi Krugman (1980, 1983), Caprio ve Clark (1981) ve Golub (1983) gibi çalışmalarda petrol ihraç eden ve ithal eden ülke paraları arasındaki kur açısından ele alınmaktadır. Fakat Rusya ile güçlü ekonomik ilişkilere sahip olunması, petrol fiyatlarındaki değişmelerin Kazakistan reel döviz kuru üzerindeki etkisinde bir farklılığa neden olması beklenir. Çünkü petrol fiyatlarındaki artışın, petrol ihraç eden ticaret ortağı ülkenin de ulusal parasının değerlenmesine ve dolayısıyla petrol dışındaki sektörlerin rekabet gücünde ortaya çıabilecek sorunların daha zayıf şekilde ortaya çıkmasına neden olabilir. Diğer yandan, döviz kuru üzerinde, artan petrol gelirlerinin yabancı mallara ve varlıklara harcanmasından kaynaklanan dolaylı etkilerin de, petrol ihraç eden ve ithal eden ülke örneğinden farklı olması beklenir.

Bu çalışmada, reel petrol fiyatları ile reel döviz kuru arasındaki ilişki, zengin 
petrol rezervlerine sahip Kazakistan için incelenmiştir. Bu amaçla, Kazakistan Merkez Bankasınca hesaplanan üç reel döviz kuru göstergesi kullanılmıştır. Bunlardan ilki, Kazakistan’ın ticaret yaptığı ülkelerin tamamının dikkate alınmasıyla hesaplanan reel efektif döviz kuru endeksidir. İkincisi, hesaplanmasında sadece Bağımsız Devletler Topluluğu (BDT) ülkelerinin dikkate alındığı reel efektif döviz kuru endeksidir. Üçüncü reel döviz kuru göstergesi ise, BDT dışındaki ülkeleri kapsamaktadır. Kazakistan’ın dış ticaret dağılımı dikkate alındığında, petrol fiyatları ve reel döviz kuru arasındaki ilişkiye yönelik genel bir sonucun ya da değerlendirmenin eksik olabileceği düşünülmektedir. Petrol fiyatlarındaki dalgalanmaların, ekonomide farklılık gösteren sonuçlara neden olabileceği, reel döviz kuruna ilişkin farklı göstergelerin dikkate alınmasıyla belirlenebilir.

Doğal kaynak bakımından zengin olan ülkelerin uzun dönemde daha düşük büyüme oranlarına sahip olacağını öngören ve doğal kaynak gazabı olarak ifade edilen görüş açısından da petrol fiyatlarının Kazakistan reel döviz kuru üzerindeki etkisi önem taşımaktadır. Doğal kaynak gazabının test edilmesine yönelik çalışmalar Sachs ve Warner'in (1995) doğal kaynak donanımın ekonomik büyümeyi negatif yönde etkilediğini destekleyen sonuçları ile birlikte artış göstermiştir. Doğal kaynak zenginliğinin uzun dönem büyüme oranının hangi kanallarla negatif yönde etkilediğine ilişkin farklılık gösteren görüşler mevcuttur. Buna göre doğal kaynak zenginliği imalat sanayinin küçülmesi, kurumsal kalite düşüklüğü ve eğitim düzeyinin yetersizliği gibi ekonomik faaliyetleri dışlayıcı faktörlere neden olmaktadır. Kazakistan'da doğal kaynak gazabının geçerliliğine yönelik incelemelerde, bu faktörlerin birbirini tamamlayıcı bir nitelik gösterdiği beklenebilir (Togay 2009: 221222). Bu çalışmada petrol fiyatlarının reel döviz kuru üzerindeki etkisine ilişkin sonuçlar, Kazakistan ekonomisinin böyle bir soruna karşı ne derecede açık olduğuna ilişkin de bilgi sunacaktır.

Takip eden bölümde petrol fiyatları ve döviz kuru ilişkisine yönelik teorik tartışmaya ve uygulamalı literatüre yer verilmiştir. Üçüncü bölümde Kazakistan ekonomisinin genel görünümüne ve reel döviz kurunu etkileyebilecek değişkenlere ilişkin bilgi verilmiştir. Ardından, reel döviz kuru istikrarının sağlanmasında etkili olması beklenen petrol ve doğalgaz hariç endüstrilerin gelişmesine zemin hazırlayacak olan yapısal ve kurumsal reformlar değerlendirilmiştir. Beşinci bölümde, Kazakistan merkez 
bankasının para politikası uygulamaları reel döviz kuru ve reel petrol fiyatlarının seyri ile birlikte ele alınarak aktarılmıştır. Uygulamanın yer aldığı altıncı bölümde öncelikle veri seti tanıtılmış, reel döviz kuru ve reel petrol fiyatları arasındaki ilişkinin incelenmesine yönelik uygulanan ekonometrik yöntem tanıtılarak analiz bulguları sunulmuştur. Son bölümde ise bulgular doğrultusunda değerlendirmeler yapılmıştır.

\section{Teorik Tartışma ve Ampirik Literatür}

Dünya enerji fiyatlarındaki dalgalanmalar, enerji ihracatçısı ve ithalatçısı ülkelerin dış ticaret dengesini farklı yönlerde etkilemektedir. Enerji fiyatlarının yükselmesi petrol ya da doğalgaz zengini ülkelerin ihraç gelirlerinin artmasına ve bu nedenle para birimlerinin değerlenmesine neden olabilmektedir. Diğer yandan, bu durum petrol ve doğalgaz hariç diğer sektörlerin rekabet edebilme kabiliyetlerinin azalmasiyla ve ekonominin sektörel yapısında petrol ve doğalgaz sektörlerinin öneminin artmasıyla sonuçlanabilmektedir. Doğal kaynak zenginliğinin imalat sanayinin küçülmesi şeklinde ortaya çıkması ya da imalat sanayide ekonomik faaliyeti dışlaması Hollanda hastalığı olarak bilinmektedir. Enerji fiyatlarının artması petrol ve doğalgaz ithal eden ülkelerde ise, dış ticaret dengesinin olumsuz etkilenmesine ve bu ülkelerin para birimlerinin değer kaybetmesine neden olabilmektedir. Aynı zamanda, enerji fiyatlarının artmasının ithalatçı ülkelerde maliyet enflasyonuna neden olması da beklenir. Dolayısıyla, dünya petrol fiyatları ülkelerin dış ticaret dengesini doğrudan etkileyerek ve ülkelerin döviz rezervlerini ve reel döviz kurunu değiştirici sonuçlara neden olabilmektedir.

Petrol fiyatlarındaki değişmelerin, ödemeler dengesinde ve dolayısıyla reel döviz kuru üzerinde neden olduğu doğrudan etkinin yanı sıra, dolaylı etkilerinin olması da beklenir. Dolaylı etkiler, petrol ihraç eden ülkenin ihraç gelirlerini harcamasından ve yatırımlarından kaynaklanır. Şöyle ki, petrol fiyatlarındaki bir artış başlangıçta ithalatçı ülkenin ithalatını artırmaktadır. Fakat ihracatçı ülkenin artan petrol gelirlerini ithalatçı ülkenin mallarına ve varlıklarına harcaması, petrol ithal eden ülke açısından olumlu dolaylı etkilerin ortaya çıkmasına neden olmaktadır. Dolayısıyla, petrol fiyatlarındaki artışının döviz kuru üzerindeki başlangıç ve nihai etkileri farklılık gösterebilmektedir (Krugman 1980: 10). Dolaylı etkinin güçlü bir şekilde ortaya çıkmasında, başlangıçtaki doğrudan etki sebebiyle ulusal para 
biriminin değerlenmesi sonucu petrol ve doğalgaz hariç diğer endüstrilerin uluslararası rekabet gücünü kaybetmesi ve yeni endüstrilerin gelişememesi etkili olmaktadır. Bu sebepledir ki, petrol ihraç eden ülkelerde artan gelir düzeyi ile birlikte ithalatta daha süratli bir artış da ortaya çıkabilmektedir.

Krugman (1980), petrol fiyatlarındaki artışın döviz kuruna etkisinin üç faktöre bağlı olduğunu ifade etmektedir. Bunlardan ilki, petrol ihraç eden ülkenin dış varlıkları içinde ithalatçı ülke menşeli olanların oranıdır. İkinci faktör, petrol ihraç eden ülke ithalatında petrol ithal eden ülke mallarının oranıdır. Üçüncü faktör ise, petrol ithal eden ülkenin dünya petrol ithalatında sahip olduğu paydır. Petrol fiyatındaki artışın döviz kuru üzerindeki etkisi kısa dönemde birinci ve üçüncü faktörlerin, uzun dönemde ise ikinci ve üçüncü faktörlerin nispi büyüklüklerine bağlıdır. Yani, petrol fiyatlarındaki artışın kurlar üzerindeki etkisi kısa dönemde petrol ihraç eden ülkenin dış varlıkları içinde petrol ithal eden ülke menşeli olanların payının petrol ithal eden ülkenin dünya petrol ithalatındaki payından fazla olup olmamasına bağlıdır. Uzun dönemde ise, petrol ithal eden ülkenin dünya petrol ithalatındaki payı ile petrol ihraç eden ülkenin ithalatı içinde petrol ithal eden ülke menşeli malların payı etkili olmaktadır. Böylelikle, daha yüksek petrol fiyatlarının ödemeler dengesi etkisi azalan bir şekilde petrol ihraç eden ülkenin varlık tercihlerine ve artan bir şekilde mal tercihlerine bağlı olmaktadır. Uzun dönemde, petrol ihraç eden ülkenin varlık yatırımları sona erer ve yukarıda ikinci ve üçüncü faktör şeklinde ifade edilen ithalat ve ihracat paylarının karşılaştırılması önem kazanır (Krugman 1980: 9-10).

Petrol fiyatındaki artış petrol ithal eden ülkenin ödemeler dengesini doğrudan olumsuz yönde etkilemekte, fakat petrol ihraç eden ülkenin artan gelirlerini petrol ithal eden ülkenin mallarına ve varlıklarına harcaması ödemeler dengesini dolaylı olarak iyileştirmektedir. Fakat petrol fiyatlarının kurlara etkisi için, petrol ithal eden ülke açısından bakıldığında, ülkenin petrol ithal ettiğinin ve ithalat talep esnekliğinin düşük olduğunun bilinmesi yeterli değildir. Bunun dışında, ithalata olan nispi bağımlılığın yüksek olması, nispi talep esnekliğinin düşük olması ve petrol ihraç eden ülkenin yabancı mallara ve varlıklara yönelik artan harcamalarından petrol ithalat eden ülkenin aldığı payın nispi olarak düşük olması durumunda petrol fiyatlarındaki artış, petrol ithal eden ülke parasının değer kaybetmesine neden olur (Krugman 1983: 259-260). 
Caprio ve Clark'ın (1981) teorik sonuçlarına göre ise, petrol fiyatlarındaki artışın döviz kurlarına etkisi, petrol ihraç eden ülkenin yanı sıra petrol ithal eden ülkenin portföy tercihlerine de bağlıdır. Bunun dışında, cari hesap dengesinin durumu da petrol fiyatı değişmelerinin döviz kuru sonuçlarını etkiler. Fakat bu etkinin anlaşılabilmesi, ilk etkide ifade edilen varlık tercihlerinin bilinmesi koşuluyla ancak mümkündür. Nihayet son olarak ise, ülkelerin artan petrol fiyatına uyumunu yansıtan döviz kuru beklentileri de, cari spot kurun belirlenmesinde etkili olmaktadır (Caprio ve Clark 1981: 17-18).

Benzer bir şekilde Golub’a (1983) göre de petrol fiyatlarındaki değişmelerin reel kur üzerindeki etkisi, ithalat kalıbına ve portföy tercihlerine bağlı olarak değişebilmektedir. Petrol fiyatlarındaki artış gelir, cari hesap dengesi, tasarruflar gibi makroekonomik akımları etkilemektedir. Bu akımlar varlık stokunu ve bunların petrol ihraç ve ithal eden ülkeler arasındaki dağılımını değiştirmektedir. $\mathrm{Bu}$ nedenle, petrol fiyatlarındaki değişmelerin kurlar üzerindeki etkilerinin belirlenmesinde cari hesap dengesi ve sermaye hesab1 üzerinden etkilerin birlikte değerlendirmesi gerekmektedir (Golub 1983: 576-577).

Petrol fiyatları ve döviz kuru ilişkisi uygulamalı çalışmalarda da geniş bir şekilde ele alınmıştır. Mevcut literatürde konu, hem petrol ithal eden, hem de ihraç eden ülkeler için farklı yöntemler kullanılarak incelenmiştir. Çoğunlukla koentegrasyon ve nedensellik tekniklerinin kullanıldığı Chaudhuri ve Daniel (1998), Amano ve Norden (1998a ve 1998b), Chen ve Chen (2007), Zhang, Fan, Tsai ve Wei (2008), Wang ve Wu (2012) ve Zhang (2013) gibi çalışmalar petrol ithal eden gelişmiş ülkeler için yapılmıştır. Genellikle, uzun dönem ilişkiyi destekleyici sonuçlar elde edilmiştir. Gelişmekte olan ülkelere yönelik yapılan çalışmalarda ise Huang ve Guo (2007), Chen, Lee ve Goh (2013), Turhan, Hacihasanoglu ve Soytas (2013), Bal ve Rath (2015) ve De Vita ve Trachanas (2016) farklllik gösteren sonuçlar elde etmişler. Bu çalışmalarda, petrol fiyatlarındaki artışın gelişmekte olan ülkelerin paralarının değerlenmesi yönünde sonuçlara neden olduğu kısmen desteklenmektedir. Rautava (2004), Koranchelian (2005), Zalduendo (2006), Habib ve Kalamova (2007), Korhonen ve Juurikkala (2007), Nikbakht (2010), Jahan-Parvar ve Mohammadi (2011), Hasanov (2010) ve Ağazade (2018) çalışmaları ise OPEC üyeleri ya da diğer petrol 
ihraç eden ülkelere ilişkindir. Bu çalışmalarda çoğunlukla petrol fiyatlarının reel döviz kurunu pozitif yönde etkilediğine yönelik sonuçlara ulaşılmışıtır.

Petrol fiyatları ve döviz kuru ilişkisi Kazakistan’ın da dahil edildiği bazı panel çalışmalarda araştırılmıştır. Fakat literatürde, bu ülke için zaman serisi verilerinin kullanıldığı tek bir çalışmaya rastlanmıştır. Bu çalışma Kutan ve Wyzan (2005) tarafından gerçekleştirilmiş olup, ARCH modeli dahilinde en çok olabilirlik yöntemine dayanmaktadır. Ocak 1996 - Kasım 2003 dönemine ait veri setinin kullanıldığı çalışmada petrol fiyatlarındaki değişmelerin reel döviz kuru hareketleri üzerinde önemli etkiye sahip olduğu sonucuna varılmıştır.

Kazakistan için doğal kaynak gazabının geçerliliği ise Ibadildin (2011), Oskenbayev ve Karimov (2013), Oskenbayev (2015) ve Aliev (2015) gibi çalışmalarındafarklıekonomik, politikve toplumsal göstergelerdekigelişmeler çerçevesinde incelenmiştir. Ibadildin (2011), ekonomik göstergeler dikkate alındığında doğal kaynak gazabının geçerliliğine ilişkin değerlendirmelerin farklılaşabileceğini ifade etmektedir. Fakat politik gücün yoğunlaşması, özgürlüklerin ve hakların sınırlandırılması ve yolsuzlukların yaygınlığına ilişkin göstergelerle kurumsal kapasitedeki sınırlı gelişmelerin doğal kaynak gazabının politik bakımdan geçerliliği için destekleyici nitelikte olduğunu belirtmiştir. Üretimin çeşitlendirilmesine yönelik politika önceliğine rağmen ekonomide ve bütçe gelirlerinde petrol sektörünün payının yıllar itibariyle artış gösterdiği vurgulanmıştır. Kazakistan eyaletlerine ait verileri kullanarak Oskenbayev ve Karimov (2013) ise, petrol ve doğalgaz gibi zenginliklerin yanı sıra tarımsal ürün üretimini de dikkate almış ve Hollanda hastalığının incelenmesi için ticaret ve ticaret dışı sektörlerin nispi fiyatlarını büyüme modeline dahil etmişlerdir. Çalışmada ticaret dışı sektörlerdeki fiyat artışlarının ticaret sektöründe maliyetlerde daha yüksek artışlara neden olduğu görülmüştür. Tarım ürünlerinin fiyatlarındaki dalgalanmaların da ekonomik büyümeyi olumsuz yönde etkilediği yönünde sonuçlar elde edilmiştir. Buğday fiyat artışlarının, kurumsal etkinsizliğe neden olduğu ve tarım sektöründe aracıların rant kollama faaliyetlerinde ortaya çıkan artışın büyümeyi zayıllattığı yönünde değerlendirme yapılmıştır. Oskenbayev (2015) de, doğal kaynak gelirlerine ait payların yüksek olmasının kurumsal kaliteyi negatif yönde etkilediği ve bunun ekonomik büyümeyi olumsuz yönünde etkilediği şeklinde sonuçlar elde etmiştir. Benzer şekilde Aliev 
(2015) de 2000’lerdeki aktif ekonomik değişime rağmen doğal kaynak zenginliğinin büyüme kalitesi üzerinde negatif etkiye sahip olduğunu ifade etmiştir. Buna göre Kazakistan yapısal, bölgesel ve toplumsal eşitsizlikler sergilemektedir ve temel mallar dahil ürünlerinin çoğu bakımından düşük uluslararası rekabet gücüne sahiptir.

Literatürde petrol fiyatlarının döviz kuru etkisi, konuya ilişkin teorik çalışmalarda, genellikle petrol ithal ve ihraç eden ülkeler şeklinde bir sınıflamaya gidilerek ele alınmıştır. Kazakistan petrol ihraç eden bir ülke olmakla birlikte, aynı özelliğe sahip olan Rusya ile güçlü ekonomik ilişkilere sahiptir. Azerbaycan, Türkmenistan ve İran gibi petrol ihraç eden ülkeler de Kazakistan'ın dış ticaretinde küçük paylara sahiptir. Bu nedenle Kazakistan teorik çalışmalardaki standart petrol ihraç eden ülke profilinden farklılık göstermektedir ve petrol fiyatlarındaki dalgalanmaların Kazakistan reel döviz kuru üzerindeki etkisi tamimiyle aynı şekilde olmayabilir. Uygulamalı çalışmalara ilişkin sonuçlar ise, petrol fiyatlarındaki artışların petrol ihraç eden ülkelerde reel döviz kurunu genellikle artırıcı sonuçlara neden olduğunu destekleyici niteliktedir. Fakat ilgili literatürde yeteri kadar ele alınmadığı görülen Kazakistan için de konunun araştırılması önem taşımaktadır. Petrol ihraç eden bir ülke olmakla birlikte Rusya ve diğer bazı BDT ülkeleri ile yoğun ticaret ilişkisine sahip olması Kazakistan için bu özel ilgiyi gerektirmektedir.

\section{Kazakistan Ekonomisinin Görünümü ve Petrol Sektörü}

2015 yıllında Kazakistan GSYH'si cari fiyatlarla 184,39 milyar dolar olmuştur. 2014 yılında ise bu rakam 221,42 milyar dolardır. Sovyetler Birliği sonrası dönemde Kazakistan'ın büyüme performansını ise, kısaca şu şekilde özetlemek mümkündür. 1991 yılına ait GSYH cari fiyatlarla yaklaşık olarak 24,88 milyar dolar olmuştur (Dünya Bankası 2016). Geçiş ekonomileri için geçiş dönemi durgunluğu şeklinde karakterize edilen 1990’lı yılların başlarında, Kazakistan ekonomisi önemli sorunlar yaşamıştır. Bazı yıllarda, GSYH artış oranı eksi işaretle \%10'un üzerinde olmuştur. 1995 yılında reel GSYH, 1990 yılına ait değerinin \%61,16'na eşit olmuştur (Ağayev 2013: 373). Düşük pozitif büyüme oranlarının gerçekleştiği 1996 ve 1997 yıllarından sonra 1998 yılında Kazakistan ekonomisi, Rusya krizinin etkisi ile tekrar küçülmüştür. 1999 ve sonrası yıllarda ise Kazakistan sürekli pozitif büyüme oranlarına sahip olmuştur. 2000-2007 yıllarını kapsayan 8 yıllık 
dönemde ortalama reel GSYH büyümesi \%10'un üzerinde olmuştur. Küresel finansal krizin etkisi ile 2008 ve 2009 yıllarında önceki yıllarla karşılaştırıldığında Kazakistan hayli düşük oranda büyümüştür. 2010-2013 yıllarında ise büyüme oranlarında toparlanma gözlense de, dünya enerji fiyatlarının düşüş gösterdiği 2014 ve 2015 yıllarında büyüme oranları sırasıyla \%4,20 ve \%1,20 olmuştur (Dünya Bankası 2016).

GSYH dalgalanmalarında olduğu gibi, ihracatın Kazakistan ekonomisindeki payı da dünya petrol fiyatlarındaki değişmelerle paralellik göstermiştir. 2000’li yıllarda ihracatın GSYH oranı 2009 yılına kadar genellikle \%50'lerin üzerinde seyretmiştir. 2009 ve sonrasında ise bu oran genellikle \%40 düzeyinde olmuştur. Bu istatistiğin, 2014 ve 2015 yıllarına ait değerleri ise sırasıyla yaklaşık olarak \%39,34 ve \%28,46 olmuştur (Dünya Bankası 2016).

Kazakistan önemli derecede petrol ve doğalgaz rezervine sahiptir ve ekonomisinde petrol ve doğalgaz sektörlerinin ağırlığı artmaktadır. Kazakistan'ın kanıtlanmış petrol rezervlerinin miktarı 30 milyar varildir. Doğalgazda ise bu rakam 0,9 trilyon metre ${ }^{3}$ tür. $\mathrm{Bu}$ değerler sırasıyla kanıtlanmış dünya petrol rezervlerinin yaklaşık olarak \%1,8’ini ve doğalgaz rezervlerinin ise \%0,5'ini oluşturmaktadır. Kazakistan 2015 yılında dünya petrol üretiminin $\% 1,8^{\prime}$ ini ve doğalgaz üretiminin $\% 0,3$ 'ünü gerçekleştirmiştir (BP 2016: 6-22). Bir önceki yıl ile karşılaştırıldığında, 2015 yllında Kazakistan’ın petrol ve doğalgaz üretimine ait fiziki hacim endeksi \%4,5 oranında küçülmüştür. Bununla birlikte, bu sektörlerin GSYH içindeki payı \%17,3 olmuştur (KCS 2016: 2).

Kazakistan ihracatında petrol ürünlerinin payı da önemli derecede yüksektir. Bu orana ilişkin istatistikler, 2000 öncesi yıllarda toplam ihracat içinde petrol ürünlerinin payının \%50'nin altında olduğunu gösterir. Sonraki yıllarda ise, petrol ürünleri payının bir artış trendine sahip olduğu ve 2014 yılında yaklaşık olarak \%76,63 oranında gerçekleştiği görülmektedir. Bu oran, 2015 yılında petrol fiyatlarındaki düşüşün etkisi ile bir miktar gerileyerek $\% 68,02$ olmuştur (Dünya Bankası, 2016). Bunun yanı sıra BM Ticaret ve Kalkınma Konferansı'nın (UNCTAD) ihracat yoğunlaşma endeksi de Kazakistan'ın bağımsızlık sonrası dönemde ihracatını çeşitlendiremediğini ve bunun aksi yönünde gelişme yaşandığını göstermektedir. Bu endekse ait değer 1995 yılında 0,20 iken, bir artış trendi göstererek 2015 yılında 0,66 olmuştur. Aynı yıllarda ihraç edilen ürün sayısı ise sırasıyla 206 ve 217 olmuştur. 
Kazakistan'a ait cari hesap dengesi verilerine bakıldığında ise, 2005 - 2007 yıllarında ve küresel finansal krizin yaşandığı 2009 yılında dengenin açık verdiği görülmektedir. Yine petrol fiyatlarının düşük olduğu 2015 yılında, cari hesap dengesi 5823,2 milyon dolar açık vermiştir. 2014 yılına ait denge değeri ise 4643,46 milyon dolar fazla olmuştur. 2014 ve 2015 cari hesap dengelerinin GSYH oranları ise sırasıyla yaklaşık olarak \%2,69 ve -\%2,96'dır (Dünya Bankası 2016).

Yeni petrol ve doğalgaz madenlerinin işletmeye açılması ile sağlanan üretim artışı ve petrol fiyatlarının yüksek düzeyde seyretmesi 2000'li yıllarda Kazakistan ekonomisinin güçlü büyüme göstermesine neden olmuştur. Fakat ihracat yoğunlaşma endeksi ile ihraç edilen ürün sayısına ilişkin istatistikler petrol ve doğalgaz hariç endüstrilerde gelişmeye yönelik sorunların varlığına ya da Hollanda hastalığı belirtilerine işaret etmektedir.

\section{Yapısal ve Kurumsal Dönüşüme Yönelik Reform Çabaları}

Petrole bağımlılığın yarattığı nedenlerin ortadan kaldırılması ya da etkilerinin azaltılması, Kazakistan ekonomisi için, en önemli gündem maddesidir. Böyle bir dönüşümün sağlanması, bir dizi yapısal ve kurumsal reformu gerekli kılmaktadır (Togay 2009: 219). Fakat Kazakistan'ın oldukça büyük yüzölçümüne nispeten küçük bir nüfusa sahip olması iç talebin kısıtlı kalmasına neden olurken, ekonomide çeşitlendirmenin gerçekleştirilmesini de zorlaştırmaktadır (Aliev 2015: 4). Ayrıca yetmiş yılı aşkın bir komünist idaresinden sonra mülkiyet hakları, ifade özgürlüğü, politik kontrol ve denge mekanizmaların kısa bağımsılık döneminde hızlı şekilde kurulmasını beklemek aşırı iyimserlik olarak görülebilir (Ibadildin 2011: 12). Diğer yandan kurumsal düzenlemelerinin, bütçe desteği gibi hükümet politikalarının, taşıma ve ihracat maliyetlerini karşılamak için gerekli finansal kaynakların ve toprağa ilişkin mülkiyet haklarının neden olduğu büyük ölçekli üreticiler tarım sektörünün rekabetçi olmayan ve reformları engelleyici bir yapıda olmasına neden olmaktadır (Oskenbayev 2015: 133).

Dünya Ekonomik Forumu (WEF) ülkelerin temel kurumsal ve ekonomik göstergelerine, verimlilik artışı sağlayabilecek faktörlere ve yenilikçilik ile ekonomik faaliyetin gelişmişliğine yönelik küresel rekabet gücü endeksleri yayınlamaktadır. Kazakistan'a ait bu endekslerin incelenmesi ile ülkede 
yapısal ve kurumsal değişime ilişkin bilgi sağlanabilir. 12 başlıkta toplanan WEF rekabet gücü endeksleri kurumlar, altyapı, makroekonomik ortam, sağlık ve ilköğretim, yükseköğrenim ve mesleki eğitim, mal piyasası etkinliği, emek piyasası etkinliği, finansal piyasa gelişmeleri, teknolojik hazırlık, piyasa genişliği, iş dünyasının gelişmişliği ve yenilikçilik endeksleridir. $\mathrm{Bu}$ göstergelerden her biri çok sayıda nicel ve nitel özelliklere ilişkin alt endekslerden hesaplanmakta olup 1 ile 7 arasında değişmektedir. 1 ilgili gösterge açısından ülkenin herhangi bir rekabet gücüne sahip olmadığını, 7 ise ilgili gösterge bakımından ülkenin en iyi durumda olduğunu ifade etmektedir.

Kurumlar başl ğ̆ı ile ifade edilen endeks mülkiyet hakları, politikacı güveni, rüşvet, yargı bağımsızlı̆̆ı, kamu harcamalarında israf, yasal çerçevenin etkinliği, devlet kurumlarının şeffaflığı, suç ve şiddet, polis hizmetlerinin güvenilirliği, firmaların davranış etiği, kurumsal kuralların etkinliği, azınlık hakları gibi bir dizi alt endeksin ortalaması şeklinde hesaplanmaktadır. Kazakistan'a ait kurumlar endeksinin 2006 yılına ait değeri 3,59 iken 2016 yılına kadar sadece 1 lımlı bir artış göstererek 4,23 olmuştur ve 2016 yılına ait ülkeler sıralamasında Kazakistan 138 ülke arasında 49'cu sırada yer almıştır. Ülkenin ulaştırma, enerji ve iletişim altyapısına ilişkin endeks açısından ise 63 'cü sırada olmuştur. Bütçe dengesi, kamu borcu, tasarruf oranı, enflasyon oranı ve ülke kredi notuna ilişkin verilerden hareketle hesaplanan makroekonomik ortam endeksine ait 2006 ve 2016 değerleri sırasıyla 5,89 ve 4,65 olmuştur. Bu endeksin son gözlem değerine göre ülke Kazakistan 69'cu sırada bulunmaktadır.

Mal piyasası etkinliği endeksi petrol ve doğalgaz hariç endüstrilerin gelişmesi açısından önemli bir göstergedir. Bu göstergede yerel piyasalarda rekabet yoğunluğu, firmaların piyasa hakimiyet düzeyi, anti monopol politikaların etkinliği, vergilendirme yatırım güdüsüne etkisi, kârlar üzerinden toplam vergi oranı, şirket kurmak için gerekli prosedür sayısı, şirket kurmak için gereken gün sayısı, tarım politikası maliyetleri, ticaretin önündeki engellerin yaygınlığı, ticaret tarife oranları, yabancı mülkiyetin yaygınlığı, doğrudan yabancı sermayeye yönelik düzenleyici kurumların işletme etkisi, gümrük prosedürünün getirdiği yük, ithalatın GSYH oranı, tüketici odaklılık düzeyi ve tüketicinin bilgi ve farkındalık düzeyi alt endekslerin ortalaması şeklinde hesaplanmaktadır. Kazakistan'ın mal piyasası etkinliği endeksine ait değeri 
2006-2016 yılları arasında ihmal edilebilir bir artışla 4,28'den 4,39'a yükseldiği görülmektedir. Bu endeksin 2016 yılı değerine göre Kazakistan 138 ülke arasında 62'ci sırada bulunmaktadır.

Aynı derecede önemli olan bir diğer WEF endeksi finansal piyasaların gelişmişlik düzeyine ilişkindir. Fakat Kazakistan ait istatistikler bu alanda herhangi bir ilerleme sağlanmadığını, aksine endeks değerinin bir azalma trendine sahip olduğunu göstermektedir. 2006 ve 2016 yılları için endeks değerleri sırasıyla 4,21 ve 3,50 olmuştur. Finansal piyasalarda gelişmeler endeksine göre 2016 yılında Kazakistan 138 ülkenin yer aldığı ülkeler sıralamasında 104 'cü olmuştur. Finansal piyasalarda gelişmeler endeksin hesaplanmasında firma gereksinimlerini karşılayan finansal hizmetler, finansal hizmetlerin ekonomikliği, yerel sermaye piyasaları aracılığıyla finansman, kredilere erişim kolaylığı, girişim sermayesinin mevcudiyeti, bankaların sağlamlığı, menkul kıymetler borsalarının düzenlenmesi ve borçlu ve alacaklı haklarının korunmasına ilişkin endeksler kullanılmaktadır.

İş dünyası gelişmişliği ve yenilikçilik endeksleri, WEF’nin yenilikçilik temelli rekabet gücü ile ilişkilendirdiği endeklerdir. Her iki endekse ait değerler finansal piyasalara ilişkin endeks hariç diğer endekslerle karşılaştırıldığında düşük oldukları görülmektedir. İş dünyasının gelişmişliği endeksi yerel tedarikçilerin sayısı ve kalitesi, kümelenme geliştirme durumu, rekabet üstünlüğünün doğası, değer zinciri genişliği, uluslararası dağıtımın kontrolü, üretim sürecinin sofistike olması, pazarlama kapsamı ve iş hayatında yöneticilerin yetki devrine istekli olmalarına ait değerlerle hesaplanmaktadır. Bu endekse göre Kazakistan 2006-2016 yılları arasında iş dünyası gelişmişliği bakımından herhangi bir ilerleme sağlayamamışır. Belirtilen yıllara ait endeks değerleri 3,75 ve 3,64'dür. 2016 yılı değerine göre ülke sırası ise 96 olmuştur. Yenilikçilik endeksinin hesaplanmasında ise yenilik kapasitesi, bilimsel araştırma kurumlarının kalitesi, firmaların ar-ge harcamaları, ar-ge'de üniversite sanayi işbirliği, kamuda gelişmiş teknoloji kullanımı, bilim adamlarının ve mühendislerin mevcudiyeti ile patent başvurusuna ilişkin göstergeler dikkate alınmaktadır. Endeks değerinin 2006 yılında 3,14 ve 2016 yılında 3,39 olduğu ülkeler sıralamasında ise yenilikçilik açısından Kazakistan 2016 yılında 59'cu olmuştur.

Avrupa İmar ve Kalkınma Bankası (EBRD) da geçiş ekonomilerinde yapısal dönüşüme ilişkin geçiş göstergeleri olarak ifade edilen endeksler 
yayınlamaktadır. Bu endeksler de Kazakistan'da yapısal reformlara ilişkin bilgi sağlayıcı niteliktedir. 2010 yılı itibariyle 6 başlıkta ifade edilen bu endeksler büyük ölçekli özelleştirmeler, küçük ölçekli özelleştirmeler, yönetim ve kurumsal yeniden yapılanma, fiyatların liberalleştirilmesi, ticaret ve kur sistemi ve rekabet politikası endeksleridir. Her bir endeks 1 ile 4 arasında değişmektedir. Bu değerin 1 olması ilgili gösterge açısından ülkenin merkezi planlı ekonomiler, 4 olması ise gelişmiş liberal ekonomiler düzeyinde olmasını ifade etmektedir. Kazakistan küçük ölçekli özelleştirmelere, fiyatların liberalleştirilmesine, ticaret ve kur sisteminin liberalleştirilmesine yönelik yapısal dönüşüm reformlarını önemli ölçüde ve büyük ölçekli özelleştirmeleri de kısmen gerçekleştirmiş durumdadır. $\mathrm{Bu}$ endekslere ait 2014 yılı değerleri 4 veya buna çok yakındır. Fakat yönetimin ve kurumların yeniden yapılandırılması ile rekabet politikasına ilişkin endeksler 1990 'l y ylların ortalarından itibaren sabit bir şekilde 2 düzeyindedir.

Kazakistan'da yapısal dönüşüme ilişkin WEF ve EBRD verileri ülkede fiyat mekanizması, kur sistemi, dış ticaret başta olmak üzere ekonominin liberalleştirilmesine yönelik reformların gerçekleştirildiğini destekleyici niteliktedir. Fakat özellikle, finansal piyasaların gelişmişliği, iş dünyasının gelişmişliği ve mal piyasasının etkinliği bakımından önemli sorunların olduğu görülmektedir. Bunun yanı sıra, kurumsal yapının ve politik sistemin yapısal dönüşümüne ilişkin göstergeler de, bu alandaki gelişmelerin sınırlı düzeyde olduğunu göstermektedir. Ibadildin'ın (2011) Kazakistan’da devletin topluma karşı sorumlu olması, özel mülkiyet, şeffafık, yolsuzlukla mücadele, kuvvetler dengesi, güçlü parlamento, yargı bağımsızlığı, ifade özgürlüğü gibi formel ve bunların yanı sıra enformel kurumlara ilişkin değerlendirmesi de bunu desteklemektedir. Yapısal dönüşümün bu yönüne ilişkin reformlar ise, özellikle özel sektör önceliğinde gelişebilecek petrol ve doğalgaz hariç endüstriler için önem taşımaktadır.

\section{Reel Efektif Döviz Kuru ve Petrol Fiyatlarının Seyri}

Kazakistan reel efektif döviz kurunun seyri Şekil 1 yardımıyla açıklanmıştır. Şekilde reel efektif döviz kurunun üç göstergesi ve reel petrol fiyatları sunulmuştur. Bilindiği gibi, reel efektif döviz kuru ülkenin diğer ülkelerle ticaret akımlarına göre ağırlıklandırılarak hesaplanmaktadır. Grafikte sunulan ve bu çalışmada dikkate alınan üç reel efektif döviz kuru endeksi, 
tüm ülkelerin (R1), BDT ülkelerinin (R2) ve BDT dışında diğer ülkelerin (R3) dikkate alınmasıyla Kazakistan tengesi için hesaplanan reel efektif döviz kurlarıdır. Endekslerdeki artış ulusal paranın değerlenmesini, azalış ise değer kaybetmesini ifade etmektedir.

Kazakistan ulusal parası tenge 15 Kasım 1993'de 500 Rus rublesine sabitlenmiş şekilde tedavüle bırakmıştır. Fakat kısa süre sonra dalgalanmaya bırakılmasıyla süratli şekilde değer kaybetmiştir. Aralık 1993'de 5,8 olan tengenin dolar kuru Aralık 1994'te 53,7 olmuştur. Bu dönemde tenge, dolar karşısında yaklaşık olarak \%825,1 oranında değer kaybetmiştir. 1995 ve 1996 yılında ise, dolar kurunda artış oranları yılsonları itibariyle sırasıyla \%19,6 ve \%13,4 olmuştur. 1990'ların ortalarından itibaren bütçe açığının azaltılması, istikrar tedbirleri, döviz kuru ve enflasyon için hedeflerin açıklanması gibi önlemler fiyat ve döviz kuru istikrarında etkili olmuştur. Sonraki dönemde tenge dolar kuru 1998 Rusya krizine kadar istikrarlı bir seyir izlemiştir (Ağayev 2013: 373). Reel efektif döviz kuru endekslerinin Şekil 1'de verilen seyri de verinin mevcut olduğu 1995 yılı başlangıcından itibaren 1998 yılı ortalarına kadar, bu değişkenlerin ılımlı bir artış trendine sahip olduğunu gösterir. Aynı dönemde reel petrol fiyatları (P) özellikle 1997 yılının başından itibaren bir azalma trendine sahiptir.

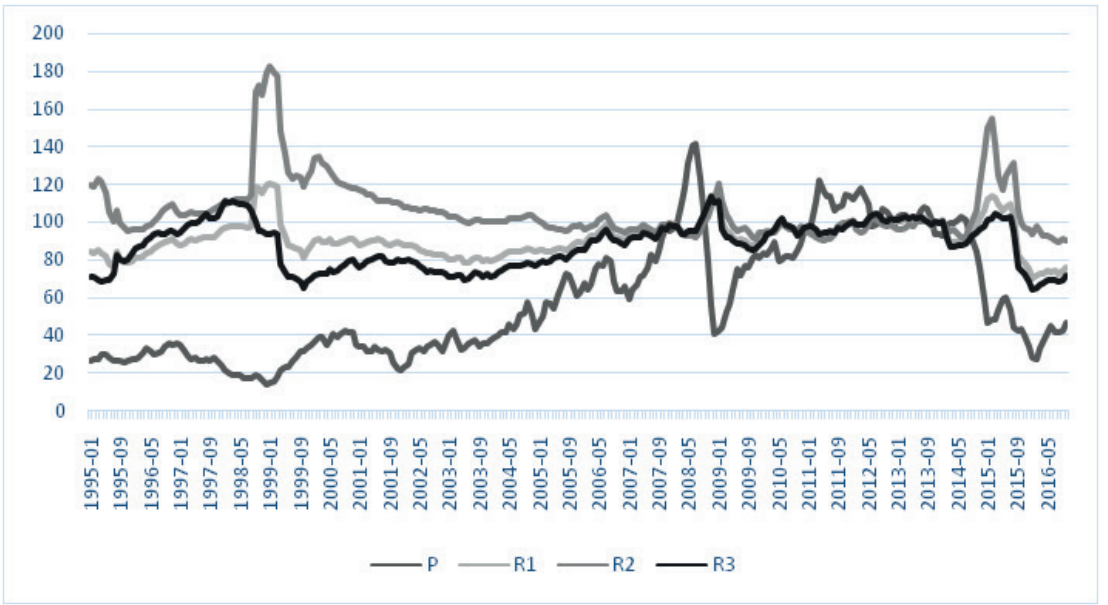

Şekil 1. Reel efektif döviz kuru endeksleri ve reel petrol fyatr

1998 Rusya krizi Kazakistan ekonomisini ciddi şekilde etkilemiştir. En önemli dış ticaret ortağına ait para biriminin yüksek oranda değer kaybetmesi ülkenin rekabet gücünü olumsuz etkilemiştir. Ağustos 1998'de 
7,6 olan rublenin dolar kuru Nisan 1999'da 25,4 olmuştur. Kazakistan ise, gözetimli dalgalanma sistemi dahilinde tengenin değer kaybetmesine 1999 Nisanına kadar izin vermemiştir. Hükümet ve Merkez Bankası yönetimi, nihayet 5 Nisan 1999'da kur politikasının sürdürülemez olması nedeniyle döviz kurunu dalgalanmaya bırakmıştır (NBK 1999).

Şekil 1'de de görüldüğü gibi, Rusya krizi döneminde R1 ve R2 reel kur endekslerinde artış, R3'te ise bir miktar gerileme olmuştur. R1'e ait değer Ağustos 1998'de 97,84 iken Mart 1999'da 119,02 olmuştur. Aynı dönemde, tengenin BDT ülkelerine karşın reel efektif döviz kurunu ifade eden R2'deki artış ise aşırı derecede yüksek olmuştur. R2 endeksi Ağustos 1998'de 115,15 iken Mart 1999'da 177,17 olmuştur. Tengenin değerlenmesine neden olan bu durum, gözetimli dalgalanma şeklinde uygulanan kur sisteminden kaynaklanmıştır. 5 Nisan 1999'da döviz kurunun dalgalanmaya bırakılması ile birlikte reel efektif döviz kuruna ait her üç endeks sert şekilde düşmüştür.

1999 yılı ortalarından itibaren tengenin dolar kuru artık daha istikrarlı bir seyir izlemeye başlamıştır. Aynı dönemde petrol fiyatları da tarihi düşük düzeyinden toparlanma eğilimindedir. 2002 yılı sonrası döneneme bakıldığında ise, küresel finansal krizin etkilerinin ortaya çıkmaya başladığı 2009 yılına kadar tengenin petrol fiyatlarındaki artışla ve Kazakistan'ın artan ihracatı ile birlikte bir miktar reel olarak değerlendiği görülmektedir. $\mathrm{Bu}$ dönemde dünya enerji ve tahıl fiyatlarının artmasının yanı sıra, Kazakistan'da özellikle doğalgaz, petrol ve tarım ürünleri üretimi de artmıştır. Şekilden de görüldüğü gibi, değer artışı R1 ve R3 reel efektif kur endekslerinde olmuştur. R2 ise aynı dönemde negatif bir eğime sahiptir. Bu durum, petrol fiyatlarındaki artışın Rusyànın da içinde bulunduğu enerji ihracatçısı olan BDT ülkelerinin ulusal paralarının da değerlenmesine neden olmasından kaynaklanmaktadır. Aynı dönemde diğer BDT ülkelerinin ihracat hacmi de önemli ölçüde artmıştır. Bu olumlu koşullarda, 14 Eylül 2004 tarihinde Kazakistan merkez bankası, para politikası rejiminde değişikliğe gideceğini, 2007 yılından itibaren enflasyon hedeflemesine geçileceğini ve öncelikli hedefinin fiyat istikrarını sağlamak olacağını açıklamıştır (NBK 2004).

Şekil 1'den de görüldüğü gibi, Temmuz 2008'e kadar reel petrol fiyatları bir artış trendine sahip olmuş ve önemli oranda yükselmiştir. Bu dönemde, 
Kazakistan'ın ihracat gelirlerinde ve yabancı sermaye girişinde yaşanan artışın tenge değeri üzerinde neden olduğu baskıya rağmen Kazakistan Merkez Bankası dolar kurunu $120 \pm \% 2$ tenge düzeyinde sürdürmüştür. Fakat petrol fiyatları Ağustos 2008'den itibaren hızlı bir şekilde düşmeye başlamışır. Bunun yanı sıra, uluslararası sermaye akımlarının yön değiştirmesi, dolar kuru için bant sisteminin uygulandığı tengenin değeri üzerinde baskı oluşmasına neden olmuştur. Şekil 1'den de görüldüğü gibi bu dönemde her üç reel kur endeksi artmıştır. Temmuz 2008 ve Ocak 2009 döneminde R1 94,63'ten 113,68'e, R2 97,48'den 120,73'e ve R3 95,61'den 111,24 'e yükselmiştir. Dolar kurunun korunmaya çalışılmasından dolayı döviz rezervlerinde ortaya çıkan azalma merkez bankasını politika değişikliğ $i$ yapma yönlendirmiştir. Merkez Bankası petrol fiyatlarınızdaki düşüşü, dış ticarette önemli paya sahip ülke paralarının değer kaybetmesini dikkate alarak ve döviz rezervlerini korumak amacıyla 4 Şubat 2009 tarihinde devalüasyona gitmiştir. Dolar kuru için yeni bant 150 tenge $\pm \% 3$ veya \pm 5 tenge şeklinde belirlenmiştir (NBK 2009). Şekil 1'den de görüldüğü gibi devalüasyon sonrası Şubat 2009'da R1, R2 ve R3 kur endeksleri sırasıyla $99,93,111,45$ ve 96,00 olmuştur.

2009 yılı ve sonrası dönemde, 2014 yılının ilk aylarına kadar Kazakistan merkez bankası dolar kurunu 145-155 bandında sürdürmeye odaklanmıştır. Fakat küresel piyasalarda emtia fiyatlarında volatilitenin artması, önemli dış ticaret partneri olan Rusya'nın daha esnek bir kur rejimi izlemesi ve 2013 yılında rublenin dolar karşısında \%7 değer kaybetmesi ve bu değer kaybının devam etmesi, ithalatta özellikle tüketim mallarından kaynaklanan bir artışın ortaya çıkması, devalüasyon beklentisinin artması nedeniyle spekülatif işlemlerin artması gibi nedenleri gerekçe göstererek spekülatif aşırılıklara karşı harekete geçme ve döviz kurunda aşırı volatiliteyi önleme adına 11 Şubat 2014 tarihinde politika değişikliğine gidilmiştir. $\mathrm{Bu}$ değişiklikle birlikte dolar kurunun mevcut düzeyde sürdürülmesinden vazgeçmiş ve dolar kurunun $185 \pm 3$ tenge bandında belirlenmesinde karar verilmiştir (NBK 2014).

2014 yılının ikinci yarısından itibaren ise, reel petrol fiyatları bir düşüş trendine girmiş ve yılsonuna doğru bu düşüş hız kazanmıştır. Temmuz 2014 'te reel petrol fiyatı 100,98 iken, Ocak 2015'te 46,20 olmuştur. Aynı dönemde reel efektif döviz kuru endeksleri ise artmıştır. Şöyle ki R1, R2 
ve R3 Temmuz 2014'te sirasiyla $89,51,92,09$ ve 88,65 'tir. Ocak 2015 'te aynı endekslere ait değerler ise $119,92,149,80$ ve 101,76 olmuştur. 15 Temmuz 2015'e kadar Kazakistan Merkez Bankası, dolar kurunun belirlenen bant içinde gerçekleşmesine yönelik politikasını sürdürmüştür. $\mathrm{Bu}$ tarihte ise, enflasyon hedeflemesi rejiminin gerektirdiği daha esnek ve aşamalı kur rejimine geçiş ve mevcut kurun bandın üst sınırında olması gerekçesiyle bant, $185-15$ ve $185+13$ şeklinde değiştirilmiştir (NBK 2015). 21 Ağustos 2015 'te ise banka, döviz piyasasına daha önceden belirlenmiş bir kur düzeyini gerçekleştirmek amacıyla müdahale etmeyeceğini ve finansal sistemin istikrarını tehdit eden aşırı döviz kuru volatilitesi önleme amacıyla müdahale hakkını saklı tutarak kurun serbest piyasa koşullarında belirleneceğini açıklamış ve enflasyon hedeflemesi para politikası rejimini uygulamaya koymuş ve \%6-8 aralığında bir yıllık enflasyon ve finansal istikrarı sağlamayı taahhüt etmiştir (NBK 2015a). Bundan sonraki dönemde, reel petrol fiyatı Şubat 2016'da 27,16 dolar düzeyine düştükten sonra 1 lımlı bir artış göstermiş ve 2016 yılı ortalarından itibaren 40 dolar düzeylerinde seyretmiştir. Reel efektif döviz kuru göstergelerinden R1 ve R3 de ılımlı bir artış trendi göstererek, Ekim 2016'da sırasıyla 75,64 ve 71,93 olmuştur. Aynı dönem için R2 ise, daha yüksek olmasına rağmen bir azalma trendine sahiptir ve Ekim 2016'da 90,62 düzeyinde gerçekleşmiştir.

\section{Veri Seti ve Araştırma Bulguları}

Çalışmada Kazakistan'da reel döviz kuru ve reel petrol fiyatları ilişkisinin incelenmesi için Ocak 1995-Ekim2016 dönemineaitverisetikullanılmıştır. Reel döviz kuru için Kazakistan Merkez Bankasının hesapladığı üç farklı gösterge kullanılmıştır. Bunlardan ilki, Kazakistan reel efektif döviz kuru endeksidir (R1). Bu endeksin hesaplanmasında Kazakistan'la dış ticaret yapan 37 ülke dikkate alınmaktadır. İkinci gösterge, tengenin BDT ülke paralarına karşı olan reel efektif döviz kurudur (R2). Üçüncü reel kur göstergesi ise, Kazakistan'ın ticaret yaptığı BDT dışındaki diğer ülke paralarına karşı tengenin reel efektif döviz kur endeksidir (R3). Reel döviz kuru endekslerdeki artış tengenin reel olarak değerlendiğini, azalışlar ise değer kaybettiğini ifade etmektedir. Reel petrol fiyatları (P) ise ABD Enerji Bilgi İdaresinden alınmış olup, ABD tüketici fiyatları endeksine göre reel değerlere dönüştürülmüş $\mathrm{ABD}$ doları cinsinden ortalama aylık ham petrol ithal fiyatlarıdır. 
Analizlerde tüm değişkenlerin logaritmik değerleri kullanılmıştır. Çalışmada öncelikle logaritmik değişkenlerin durağanlık özellikleri incelenmiştir. Bunun için üç farklı birim kök testi kullanılmıştır. Bunlar genişletilmiş Dickey ve Fuller (1981) birim kök (ADF), Phillips ve Perron (1988) birim kök (PP) ve Kwiatkowski, Phillips, Schmidt ve Shin (1992) durağanlık (KPSS) testleridir. Yaygın bir şekilde bilindiğinden dolayı bu testler burada açıklanmamıştır. Fakat testler arasındaki farklılıklar kısaca şu şekilde özetlenebilir. ADF birim kök testinde, rassal yürüyüşs sürecine ait hata terimlerinin otokorelasyonlu olabileceğinden dolayı modellere bağımlı değişken farkının gecikmeli terimleri ilave edilmektedir. PP testinde ise hata terimlerinin otokorelasyon sorununu hesaba katmak için bu gecikme değerlerini modele dahil etmeden parametrik olmayan yöntemler kullanılır. Her iki testte sıfır hipotezi serinin birim kök içerdiğini, alternatif hipotez ise serinin durağan olduğunu ifade eder. KPSS birim kök testi ise Lagrange çarpanına dayanmakta olup, sıfır hipotezi serinin durağan olduğunu ifade etmektedir.

Tablo 1. Durağanlık Testlerine Ait Sonuçlar

\begin{tabular}{lcccccc}
\hline & \multicolumn{2}{c}{ ADF } & \multicolumn{2}{c}{ PP } & KPSS \\
\cline { 2 - 6 } & Sabit & Trend & Sabit & Trend & Sabit & Trend \\
\hline LR1 & $-3,1610(1)^{\mathrm{b}}$ & $-3,0764(1)$ & $-3,0514(7)^{\mathrm{b}}$ & $-2,9529(7)$ & $0,2704(11)$ & $0,1075(11)$ \\
LR2 & $-3,5722(1)^{\mathrm{a}}$ & $-3,9002(1)^{\mathrm{b}}$ & $-3,1612(4)^{\mathrm{b}}$ & $-3,4460(4)^{\mathrm{b}}$ & $0,6625(11)^{\mathrm{b}}$ & $0,1454(11)^{\mathrm{c}}$ \\
LR3 & $-2,5811(1)^{\mathrm{c}}$ & $-2,41501(4)$ & $-2,4907(7)$ & $-2,2965(7)$ & $0,3153(12)$ & $0,1471(12)^{\mathrm{b}}$ \\
LP & $-2,0622(1)$ & $-2,5749(1)$ & $-1,7852(3)$ & $-1,9112(3)$ & $1,4447(12)^{\mathrm{a}}$ & $0,2354(12)^{\mathrm{a}}$ \\
DLR1 & $-12,1883(0)^{\mathrm{a}}-12,1951(0)^{\mathrm{a}}$ & $-12,2759(5)^{\mathrm{a}}$ & $-12,231(4)^{\mathrm{a}}$ & $0,0712(6)$ & $0,0356(6)$ \\
DLR2 & $-11,5396(0)^{\mathrm{a}}-11,5174(0)^{\mathrm{a}}$ & $-11,3838(5)^{\mathrm{a}}$ & $-11,3605(5)^{\mathrm{a}}$ & $0,0249(2)$ & $0,0251(2)$ \\
DLR3 & $-11,6253(0)^{\mathrm{a}}-11,6640(0)^{\mathrm{a}}$ & $-11,7482(6)^{\mathrm{a}}$ & $-11,7354(5)^{\mathrm{a}}$ & $0,1232(7)$ & $0,0612(7)$ \\
DLP & $-10,0230(0)^{\mathrm{a}}-10,0168(0)^{\mathrm{a}}$ & $-9,3505(10)^{\mathrm{a}}$ & $-9,3205(10)^{\mathrm{a}}$ & $0,1093(2)$ & $0,0608(2)$ \\
\hline
\end{tabular}

Not: Parantez içindeki rakamlar ADF testlerinde Schwarz bilgi kriterine göre gecikme uzunluklarını, PP ve KPSS testlerinde ise Newey-West'e göre bant genişlikleridir. ${ }^{\mathrm{a}},{ }^{\mathrm{b}} \mathrm{ve}^{\mathrm{c}}$ simgeleri ilgili istatistikin sırasıyla $\% 1,5$ ve 10 düzeyinde anlamlı olduğunu gösterir. 
Durağanlık testlerine ait sonuçlar Tablo 1'de sunulmuştur. Buna göre logaritmik reel döviz kuru değişkenlerinin (LR1, LR2 ve LR3) seviye değerlerine ait sonuçlar farklı testlerde ya da kesme ve trend içeren modellerde farklılıklar göstermektedir. Örneğin, LR1 değişkeni için tahmin edilen ADF ve PP birim kök testlerine ait sabit içeren modellere ait istatistikler birim kök içeren sıfır hipotezini reddederken, KPSS durağanlık testine ait her iki modelde durağanlığı ifade eden sıfır hipotezi reddedilememiştir. Tüm testlerde LR2 değişkeni için tahmin edilen modellerde test istatistikleri anlamlı bulunmuştur. Diğer bir reel döviz kuru göstergesi olan LR3 değişkeni için ADF ve KPSS testlerine ait sabit içeren modeller, durağanlığ 1 destekleyici sonuçlar sunmuştur. Reel petrol fiyatlarının logaritması olan LP değişkeni için ise KPSS durağanlık testine ait istatistikler anlamlı bulunmuştur. Değişkenlerin seviye değerlerine ilişkin elde edilen bulgular reel döviz kuru serilerinin durağanlığına ilişki karışı sonuçlar sunmakta, fakat LP değişkeninin birim kök içerdiğini ya da durağan olmadığını göstermektedir. Tablodan da görüldüğü gibi $\mathrm{ADF}$, PP ve KPSS test istatistikleri fark serilerinin ise durağan olduğunu ifade etmektedir.

Bilindiği gibi Engle ve Granger (1987) ile Johansen ve Jeselius (1990) koentegrasyon testleri değişkenlerin seviyelerinde olmamak üzere aynı seviyede durağan olmalarını gerektirir. Pesaran, Shin ve Smith (2001) sınır testi yaklaşımı ise seviyesinde $I(0)$ ve farkında $I(1)$ durağan değişkenler arasında da koentegrasyon ilişkisinin incelenmesine olanak tanımaktadır. Bu nedenle bu çalışmada Pesaran ve diğerleri (2001) sınır testi yaklaşımı uygulanmıştır. Bunun için ilk önce kısıtlanmamış hata düzeltme modeli tahmin edilir. LR1 ve LP değişkenleri için bu model aşağıdaki gibi ifade edilebilir:

$$
D L R 1_{t}=\alpha+\sum_{i=1}^{m} \beta_{i} D L R 1_{t-i}+\sum_{i=0}^{n} \delta_{i} D L P_{t-i}+\gamma L R 1_{t-1}+\tau L P_{t-1}+e_{t}
$$

Modelde koentegrasyon ilişkisinin incelenmesi için F testi kullanılmaktadır. Sıfır hipotezi $H_{0}: \gamma=\tau=0$ şeklindedir ve uzun dönem ilişkinin olmadığını ifade etmektedir. F testi ARDL (Autoregressive Distribution Lag) modelinde değişkenlerin durağanlık düzeylerine, açıklayıcı değişken sayısına ve modelin sabit ya da trend içerip içermediğine göre farklılık gösterir. Test sınaması için alt ve üst kritik değerler Pesaran ve diğerlerince (2001) rapor edilmiş olup, hesaplanan istatistiğin üst kritik değerden büyük olması uzun dönem ilişkisinin varlığına işaret etmektedir. 
Bu teste ilişkin sonuçlar Tablo 2'de verilmiştir. Her bir reel döviz kuru göstergesi için sabit içeren 1 numaralı eşitlik aynı zamanda trend içerecek şekilde de tahmin edilmiştir. Bu sonuçlara göre, reel döviz kuru değişkenine ait farklı göstergelerin dikkate alındığı tüm modellerde $\mathrm{F}$ istatistikleri \%5 anlamlılık düzeyinde sıfır hipotezini reddetmektedir. Bu sonuç, değişkenler arasında koentegrasyon ilişkisinin varlığını desteklemektedir.

Tablo 2. ARDL Sinur Testine Ait F Istatistikleri

\begin{tabular}{lcc}
\hline Model & Sabit & Trend \\
\hline LR1-LP & 6,9467 & 9,3260 \\
LR2-LP & 8,2655 & 8,3552 \\
LR3-LP & 7,3630 & 12,9058 \\
\hline \multicolumn{2}{c}{ \%5 Anlamlılık Düzeyi İçin Alt ve Üst Sinır Kritik Değerleri } \\
\hline I(0) & 4,94 & 6,56 \\
I(1) & 5,73 & 7,30 \\
\hline
\end{tabular}

Not: Kritik değerler Pesaran ve diğerleri (2001) çalışması sayfa 300 ve 301 'de Tablo CV(iii) ve Tablo CV(v)'den alınmıştır.

İlk aşamada uygulanan sınır testi uzun dönem ilişkinin varlığını desteklemektedir. İkinci aşamada ise aşağıdaki genişletilmiş ARDL modeli tahmin edilmiştir:

$$
L R 1_{t}=\alpha+\sum_{i=1}^{m} \beta_{i} L R 1_{t-i}+\sum_{i=0}^{n} \delta_{i} L P_{t-i}+\varepsilon_{t}
$$

LR1, LR2 ve LR3 için 2 numaralı eşitlik tahmin sonuçları sırasıyla Tablo 3, 4 ve 5 'de sunulmuştur. Tahmin edilen modellerde değişen varyans sorunu olduğundan White standart hataları kullanılmıştır. Gecikme uzunlukları ise Schwarz bilgi kriterine göre belirlenmiştir. Tablo 3'te LR1 ve LP değişkenleri için tahmin edilen trend içeren ARDL $(2,1)$ modelinde $\mathrm{LP}(-1)$ değişkenine ait katsayı istatistiksel olarak anlamlı bulunmuştur. Tablonun alt kısmında verilen bu modele ait tanımlayıcı istatistikler de modelin açıklama gücünün yüksek olduğunu, otokorelasyon sorununun, $\mathrm{ARCH}$ etkisinin ve model kurma hatasının olmadığını gösterir. Sabit içeren ARDL $(2,0)$ modelinde ise LP değişkeni katsayısı istatistiksel olarak anlamlı değildir. 
Tablo 3. LR1-LP İ̧̇in ARDL Modeline Ait Tahmin Sonuçları

\begin{tabular}{lcccc}
\hline \multirow{2}{*}{ Değişken } & \multicolumn{2}{c}{ Trend } & \multicolumn{2}{c}{ Sabit } \\
\cline { 2 - 5 } & Katsay1 & t-İstatistiği & Katsay1 & t-İstatistiği \\
\hline LR1(-1) & 1,1976 & $15,1231^{\mathrm{a}}$ & 1,2366 & $15,8298^{\mathrm{a}}$ \\
LR1(-2) & $-0,2668$ & $-3,4439^{\mathrm{a}}$ & $-0,3021$ & $-3,6589^{\mathrm{a}}$ \\
LP & $-0,0437$ & $-1,4424$ & 0,0055 & 1,1600 \\
LP(-1) & 0,0572 & $1,7264^{\mathrm{c}}$ & & \\
C & 0,2690 & $2,0941^{\mathrm{b}}$ & 0,2740 & $2,0920^{\mathrm{b}}$ \\
TREND & $-0,0001$ & $-1,5277$ & & \\
\hline $\mathrm{R}^{2}$ & 0,9212 & & 0,9183 \\
Düzeltilmiş R $\mathrm{R}^{2}$ & 0,9197 & 0,9174 \\
SC & \multicolumn{2}{c}{$-4,1139$} & $-4,1207$ \\
Breusch-Godfrey LM & $2,9504(0,2287)$ & $5,0296(0,0809)$ \\
ARCH & $0,5484(0,4597)$ & $0,4368(0,5093)$ \\
Ramsey & $0,1619(0,6878)$ & $3,9245(0,0487)$ \\
\hline
\end{tabular}

Not: ${ }^{\mathrm{a}}$, ${ }^{\mathrm{b}}$ ve ${ }^{\mathrm{c}}$ simgeleri ilgili istatistikin sırasıyla $\% 1,5$ ve 10 düzeyinde anlamlı olduğunu gösterir. Parantez içindeki sayılar ilgili istatistiğin olasılık değerleridir.

LR2 ve LP değişkenleri için tahmin edilen $\operatorname{ARDL}(2,1)$ trend ve sabit içeren modellerde LP değişkeni katsayısı negatif ve LP(-1) değişkeni katsayısı ise pozitif bulunmuş. Her iki modeldeki katsayılar istatistiksel olarak da anlamlıdır. Daha önce de ifade edildiği gibi tahminlerde White standart hataları dikkate alınmıştır. Aynı zamanda, LP değişkenine ait katsayılar mutlak değer olarak daha büyüktür. Tablonun alt kısmında verilen tanımlayıcı istatistikler gerekli özellikleri taşımaktadır ve sabit içeren modele ait Schwarz bilgi kriteri daha küçüktür. 
Tablo 4. LR2-LP İ̧in ARDL Modeline Ait Tahmin Sonuçlar

\begin{tabular}{lcccc}
\hline \multirow{2}{*}{ Değişkenler } & \multicolumn{2}{c}{ Trend } & \multicolumn{2}{c}{ Sabit } \\
\cline { 2 - 5 } & Katsay1 & t-İstatistiği & Katsay1 & t-İstatistiği \\
\hline LR2(-1) & 1,2453 & $13,0839^{\mathrm{a}}$ & 1,2454 & $13,1372^{\mathrm{a}}$ \\
LR2(-2) & $-0,3336$ & $-3,4930^{\mathrm{a}}$ & $-0,3349$ & $-3,5360^{\mathrm{a}}$ \\
LP & $-0,0804$ & $-2,2268^{\mathrm{b}}$ & $-0,0807$ & $-2,2372^{\mathrm{b}}$ \\
LP(-1) & 0,0731 & $1,7821^{\mathrm{c}}$ & 0,0708 & $1,7449^{\mathrm{c}}$ \\
C & 0,4427 & $2,7053^{\mathrm{a}}$ & 0,4548 & $2,6619^{\mathrm{a}}$ \\
TREND & $-0,0000$ & $-0,4279$ & & \\
\hline R $^{2}$ & 0,9203 & 0,9203 \\
Düzeltilmiş R ${ }^{2}$ & 0,9188 & 0,9190 \\
SC & $-3,6282$ & $-3,6485$ \\
Breusch-Godfrey LM & $1,4695(0,4796)$ & $1,2292(0,5409)$ \\
ARCH & $0,2869(0,5927)$ & $0,2759(0,5998)$ \\
Ramsey & $0,8287(0,3635)$ & $0,9997(0,3183)$ \\
\hline
\end{tabular}

Not: ${ }^{\mathrm{a}}{ }^{\mathrm{b}}$ ve ${ }^{\mathrm{c}}$ simgeleri ilgili istatistikin sırasıyla $\% 1,5$ ve 10 düzeyinde anlamlı olduğunu gösterir. Parantez içindeki sayılar ilgili istatistiğin olasılık değerleridir.

LR3 ve LP için tahmin edilen ARDL $(2,1)$ modellerinde ise $\operatorname{LP}(-1)$ değişkenine ait katsayılar pozitif ve istatistiksel olarak anlamlı bulunmuştur. LP değişkenine ait katsayılar ise anlamlı çıkmamıştır. Tablo 5 'in alt kısmında ifade edilen tanımlayıcı istatistiklerden $\mathrm{ARCH}$ istatistiği trend içeren modelde \%10, sabitli modelde ise $\% 5$ düzeyinde anlamlı çımıştır. Schwarz bilgi kriteri de trend içeren modelde daha küçüktür.

Tablo 5. LR3-LP İ̧in ARDL Modeline Ait Tahmin Sonuçları

\begin{tabular}{lcccc}
\hline \multirow{2}{*}{ Değişkenler } & \multicolumn{2}{c}{ Trend } & \multicolumn{2}{c}{ Sabit } \\
\cline { 2 - 5 } & Katsay1 & t-İstatistiği & Katsay1 & t-İstatistiği \\
\hline LR3(-1) & 1,2092 & $13,4204^{\mathrm{a}}$ & 1,2589 & $12,9167^{\mathrm{a}}$ \\
LR3(-2) & $-0,2628$ & $-2,8847^{\mathrm{a}}$ & $-0,3094$ & $-3,1140^{\mathrm{a}}$ \\
LP & $-0,0474$ & $-1,6303$ & $-0,0464$ & $-1,5324$ \\
LP(-1) & 0,0687 & $2,2019^{\mathrm{b}}$ & 0,0550 & $1,7173^{\mathrm{c}}$ \\
C & 0,1725 & $2,6211^{\mathrm{a}}$ & 0,1921 & $2,7912^{\mathrm{a}}$ \\
TREND & $-0,0001$ & $-2,4036^{\mathrm{b}}$ & & \\
\hline R $^{2}$ & \multicolumn{2}{c}{0,9602} & & 0,9583 \\
Düzeltilmiş R ${ }^{2}$ & 0,9594 & 0,9577 \\
SC & $-4,1527$ & $-4,1289$ \\
Breusch-Godfrey LM & $2,1231(0,3459)$ & $0,4369(0,8038)$ \\
ARCH & $3,2810(0,0713)$ & $3,9979(0,0466)$ \\
Ramsey & $2,6480(0,1049)$ & $0,0063(0,9370)$ \\
\hline
\end{tabular}

Not: ${ }^{\text {a }}{ }^{\mathrm{b}}$ ve ${ }^{\mathrm{c}}$ simgeleri ilgili istatistikin sırasıyla $\% 1,5$ ve 10 düzeyinde anlamlı olduğunu gösterir. Parantez içindeki sayılar ilgili istatistiğin olasıllı değerleridir. 
Tablo 6. ARDL Modellerine Ait Uzun Dönem Katsayıları

\begin{tabular}{llcccc}
\hline \multirow{2}{*}{ Model } & \multirow{2}{*}{ Değişken } & \multicolumn{2}{c}{ Trend } & \multicolumn{2}{c}{ Sabit } \\
\cline { 3 - 6 } & & Katsay1 & t-İstatistiği & Katsay1 & t-İstatistiği \\
\hline \multirow{2}{*}{ LR1-LP } & C & 0,1950 & $2,4777^{\mathrm{b}}$ & 0,0841 & 1,6207 \\
& TREND & 3,8884 & $15,1491^{\mathrm{a}}$ & 4,1803 & $19,4060^{\mathrm{a}}$ \\
\hline \multirow{2}{*}{ LR2-LP } & CP & $-0,0011$ & $-1,5686$ & & \\
& TREND & $-0,0834$ & $-0,8539$ & $-0,1104$ & $-1,6956^{\mathrm{c}}$ \\
\hline \multirow{2}{*}{ LR3-LP } & C & 5,0130 & $14,4461^{\mathrm{a}}$ & 5,0832 & $18,6451^{\mathrm{a}}$ \\
& LP & 0,3979 & $3,3774^{\mathrm{a}}$ & 0,1707 & $2,6736^{\mathrm{a}}$ \\
& TREND & $-0,0023$ & $-2,4383^{\mathrm{b}}$ & & $14,5634^{\mathrm{a}}$ \\
\hline
\end{tabular}

Not: ${ }^{a},{ }^{b}$ ve ${ }^{\mathrm{c}}$ simgeleri ilgili istatistikin sırasıyla $\% 1,5$ ve 10 düzeyinde anlamlı olduğunu gösterir.

Tablo 4, 5 ve 6'da ifade edilen ARDL modellerine ait sonuçlar LP değişkeninin LR1 ve LR3'ü pozitif LR2'yi ise negatif yönde etkilediğini gösterir. Farklı ARDL modellerine göre uzun dönem katsayılar ise Tablo 6'da verilmiştir. LR1 için tahmin edilen trend içeren model katsayısı pozitif ve istatistiksel olarak \%5 düzeyinde anlamlı bulunmuştur. Bu katsayı 0,1950'dir. LR3 için tahmin edilen modeller ise, uzun dönem ilişkiyi destekleyici daha güçlü bulgular sunmuştur. Buna göre, LR3 için tahmin edilen her iki modelde LP değişkenine ait katsayılar pozitif ve istatistiksel olarak \%1 düzeyinde anlamlı bulunmuştur. Trend ve sabit modellerde bu katsayılar sırasıyla 0,3979 ve 0,1707 'dir. Tablo 5'deki tanımlayıc istatistiklere göre LR3-LP için trend içeren model sonuçları tercih edilmiştir. LR2 için tahmin edilen modellerden ise LP değişkenine ait katsayı sabit içeren modelde negatif ve \%10 düzeyinde istatistiksel olarak anlamlı bulunmuştur. Bu katsayı $-0,1104$ 'tür.

ARDL modellerinin tahmini ve uzun dönem katsayılarının belirlenmesinden sonra kısa dönem dinamiklerin tespiti için ARDL yaklaşımına dayanan aşağıdaki hata düzeltme modeli farklı reel döviz kuru göstergeleri için tahmin edilmiştir:

$$
D L R 1_{t}=\alpha+\sum_{i=1}^{m} \beta_{i} D L R 1_{t-i}+\sum_{i=0}^{n} \delta_{i} D L P_{t-i}+\gamma E C T_{t-1}+\varepsilon_{t}
$$


Burada uzun dönem ilişkiyi ifade eden modele ait hata terimlerinin gecikmesidir. katsayısı denge ilişkisinde kısa dönemli sapmaların ortaya çıkması durumunda geriye dönüş hızını ifade etmektedir.

Tablo 7. LR1-LP İ̧̧in ARDL Hata Düzeltme Modeli Sonuçları

\begin{tabular}{lcccc}
\hline \multirow{2}{*}{ Değişken } & \multicolumn{2}{c}{ Trend } & \multicolumn{2}{c}{ Sabit } \\
\cline { 2 - 5 } & Katsay1 & t-İstatistiği & Katsay1 & t-İstatistiği \\
\hline DLR1(-1) & 0,2668 & $3,4439^{\mathrm{a}}$ & 0,3021 & $3,6589^{\mathrm{a}}$ \\
DLP & $-0,0437$ & $-1,4424$ & 0,0055 & 1,1600 \\
DTREND & $-0,0001$ & $-1,5277$ & & \\
ECT(-1) & $-0,0692$ & $-2,1143^{\mathrm{b}}$ & $-0,0655$ & $-2,0449^{\mathrm{b}}$ \\
\hline
\end{tabular}

Not: ${ }^{\mathrm{a}} \mathrm{ve}^{\mathrm{b}}$ simgeleri ilgili istatistikin sırasıyla $\% 1$ ve 5 düzeyinde anlamlı olduğunu gösterir.

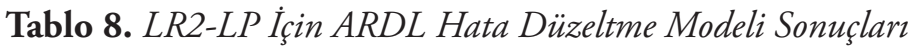

\begin{tabular}{lcccc}
\hline \multirow{2}{*}{ Değişken } & \multicolumn{2}{c}{ Trend } & \multicolumn{2}{c}{ Sabit } \\
\cline { 2 - 5 } & Katsay1 & t-İstatistiği & Katsay1 & t-İstatistiği \\
\hline DLR2(-1) & 0,3336 & $3,4930^{\mathrm{a}}$ & 0,3349 & $3,5360^{\mathrm{a}}$ \\
DLP & $-0,0804$ & $-2,2268^{\mathrm{b}}$ & $-0,0807$ & $-2,2372^{\mathrm{b}}$ \\
DTREND & $-0,0000$ & $-0,4279$ & & \\
ECT(-1) & $-0,0883$ & $-2,7721^{\mathrm{a}}$ & $-0,0895$ & $-2,7283^{\mathrm{a}}$ \\
\hline
\end{tabular}

Not: ${ }^{\mathrm{a}} \mathrm{ve}^{\mathrm{b}}$ simgeleri ilgili istatistikin sırasıyla $\% 1$ ve 5 düzeyinde anlamlı olduğunu gösterir.

Tablo 9. LR2-LP İ̧̧in ARDL Hata Düzeltme Modeli Sonuçları

\begin{tabular}{lcccc}
\hline \multirow{2}{*}{ Değişken } & \multicolumn{2}{c}{ Trend } & \multicolumn{2}{c}{ Sabit } \\
\cline { 2 - 5 } & Katsay1 & t-İstatistiği & Katsay1 & t-İstatistiği \\
\hline DLR3(-1) & 0,2628 & $2,8847^{\mathrm{a}}$ & 0,3094 & $3,1140^{\mathrm{a}}$ \\
DLP & $-0,0474$ & $-1,6303$ & $-0,0464$ & $-1,5324$ \\
DTREND & $-0,0001$ & $-2,4036^{\mathrm{b}}$ & & \\
ECT(-1) & $-0,0536$ & $-3,0733^{\mathrm{a}}$ & $-0,0505$ & $-2,9338^{\mathrm{a}}$ \\
\hline
\end{tabular}

Not: ${ }^{a}$ ve ${ }^{b}$ simgeleri ilgili istatistikin sırasıyla $\% 1$ ve 5 düzeyinde anlamlı olduğunu gösterir.

ARDL hata düzeltme modeli sonuçları Tablo 7, 8 ve 9'da verilmiştir. Hata düzeltme katsayıları tüm modellerde negatif ve istatistiksel olarak anlamlı bulunmuştur. Uzun döneme ilişkin sonuçların verildiği Tablo 6'da LR1 için tahmin edilen trend içeren modelde uzun dönem ilişki bulunmuştu. 
Tahmin sonuçları Tablo 7'de verilen DLR1 için hata düzeltme modelinde hata terimi gecikmesine ait katsayı $-0,092$ bulunmuştur. Bu, LR1 ve LPO değişkenlerinin uzun dönem denge ilişkisinde ortaya çıkan bir sapmanın \%6,92'sinin bir dönemde (burada ayda) düzeldiğini ifade etmektedir.

LR2 için tahmin edilen sabitli modelde uzun dönem katsayısı anlamlı bulunmuştu. DLR2 için tahmin edilen ve sonuçları Tablo 8'de verilen sabitli hata düzeltme modelinde hata terimi gecikmesine ait katsay1 -0,0895'tir. Buna göre LR2 ve LP uzun dönem ilişkisinde ortaya çıkan bir sapmanın $\% 8,95$ 'i bir aylık bir dönemde düzelmektedir.

LR3 ve LP için ise trend içeren ve sabitli uzun dönem modellerin her ikisinde de LP değişkeni katsayıları istatistiksel olarak anlamlı bulunmuştu, fakat modele ait tanımlayıcı istatistikler doğrultusunda trend içeren model sonuçları tercih edilmişti. Sonuçları Tablo 9'da verilen hata düzeltme modellerinde hata terimi gecikmesine ait katsayılar trend içeren ve sabitli modellerde sırasiyla $-0,0536$ ve $-0,0505$ olarak bulunmuştur. Trend içeren model sonucu dikkate alınır ise bu, LR3 ve LP'nin uzun dönem ilişkisinde ortaya çıkan bir sapmanın \%5,36'sının bir aylık dönemde düzeldiği anlamına gelmektedir. Hata düzeltme modellerinde DLP gecikmelerine ait katsayılar ise hiçbir modelde istatistiksel olarak anlamlı çıkmamıştır. Bu sonuç, değişkenler arasında kısa dönemde ilişkinin olmadığını göstermektedir.

\section{Sonuç ve Değerlendirme}

Bu çalışmada, reel efektif döviz kuru ile reel petrol fiyatları arasındaki ilişki, reel efektif döviz kuruna ait üç farklı endeks kullanılarak Kazakistan için incelenmiştir. Kur endekslerinden ilki, tengenin reel efektif döviz kurudur. Diğer iki endeks ise, BDT ülkelerinin paralarına ve Kazakistan'ın ticaret yaptığı BDT dışındaki diğer ülkelerin paralarına karşı tengenin reel efektif döviz kuru endeksleridir. Çalışmada, Ocak 1995-Ekim 2016 dönemine ait aylık veri kullanılmıştır. Uygulanan sınır testi yaklaşımı sonucunda, tüm reel efektif kur endeksleri ile reel petrol fiyatları arasında koentegrasyon ilişkisi bulunmuştur. ARDL yaklaşımı sonuçları da, reel kur endeksleri ile reel petrol fiyatları arasında uzun dönem ilişkinin varlığını desteklemiştir. Fakat uzun döneme ilişkin sonuçlar, reel petrol fiyatlarının tüm reel kur değişkenlerini aynı yönde etkilemediğini göstermiştir.

Buna göre, reel petrol fiyatları tengenin reel efektif döviz kurunu (dış ticaret yapılan tüm ülkeleri kapsayan endeks) ve tengenin BDT dışındaki ülke 
paraları karşısındaki reel efektif döviz kurunu pozitif yönde etkilemektedir. ARDL uzun dönem sonuçlarına göre, reel petrol fiyatlarında ortaya çıkan \%1'lik bir artış Kazakistan'ın reel efektif döviz kurunda yaklaşık olarak $\% 0,1950$ 'lik bir artışa neden olmaktadır. Hata düzeltme modeli sonuçları ise, bu denge ilişkisinde ortaya çıkan bir sapmanın \%6,92'sinin bir aylık bir dönemde düzelmekte olduğunu ve 14,5 aylık bir sürede ise tekrar denge ilişkisine geri dönüldüğünü göstermiştir.

BDT dışındaki ülkelerle yapılan ticaret ağılıklarına göre hesaplanan reel kur göstergesi dikkate alındığında, reel petrol fiyatlarında ortaya çıkan \%1'lik bir artısın ilgili reel kur endeksinde \%0,3979'luk bir artışa neden olduğunu gösteren sonuçlar elde edilmiştir. Hata düzeltme modeli ise, bu denge ilişkisinde ortaya çıkan bir sapmanın \%5,36'sının bir ayda ortadan kalktığını, tekrar dengeye dönüşsürecinin yaklaşık olarak 18,66 ay sürdüğünü göstermiştir.

Tengenin BDT ülkelerinin paralarına karşı reel efektif kuru dikkate alındığında ise, ARDL yaklaşımı sonuçları uzun dönem ilişkinin negatif olduğuna işaret etmiştir. Buna göre, reel petrol fiyatlarının artması, tengenin BDT ülkelerinin paraları karşısında reel olarak değer kaybetmesine neden olmaktadır. Bilindiği gibi Rusya, Türkmenistan ve Azerbaycan gibi BDT ülkelerinde petrol ve doğalgaz sektörleri ekonomide yüksek paya sahiptir. Rusya, aynı zamanda Kazakistan'ın en önemli dış ticaret ortağıdır. Bu durum dikkate alındığında petrol fiyatlarının, tengenin BDT ülke paraları karşısındaki reel kurunu negatif yönde etkilemesi anlam kazanmaktadır. ARDL yaklaşımı uzun dönem katsayılarına göre reel petrol fiyatlarında ortaya çıkan \%1'lik bir artış tengenin belirtilen reel efektif döviz kuru endeksinde $\% 0,1104$ 'lük bir azalmaya neden olmaktadır. Hata düzeltme model ise, denge ilişkisinde meydana gelen bir sapmanın \%8,95'inin bir ayda düzeldiğini, denge ilişkisine tekrar uyarlama sürecinin ise 11,17 ay sürdüğünü göstermektedir. Burada, negatif ilişkinin dışında dikkati çeken bir diğer bulgu ise diğer iki kur endeksine göre uyarlama sürecinin daha kısa olmasıdır. Bu durum, muhtemel ki Kazakistan ile diğer BDT ülkeleri arasında ekonomik ilişkilerin daha güçlü olmasından kaynaklanmaktadır.

Petrol fiyatlarındaki arışın reel döviz kurunda artışa neden olması Kazakistan ekonomisinin doğal kaynak gazabına açı olduğuna işaret etmektedir. Aynı zamanda araştırma bulguları, ülkenin dış ticaret yapısının, yani petrol ve 
doğalgaz ihraç eden bir ülke olmakla birlikte aynı özelliğe sahip Rusya ile olan ticaret hacminin yüksek olmasının reel döviz kuru istikrarını destekleyici etkilere sahip olduğunu göstermektedir. Bu yapı, petrol fiyatlarındaki dalgalanmaların reel döviz kuru üzerinde birbirini dengeleyen, farklı yönlü etkilerin ortaya çıkmasına neden olmaktadır. Diğer yandan, piyasaların etkinliği ile finansal sistemin ve iş dünyasının gelişmişliğine ilişkin göstergeler yapısal ve kurumsal açıdan sorunların varlığını destekleyici niteliktedir. $\mathrm{Bu}$ nedenle, hızlı şekilde büyüyen petrol ve doğalgaz sektörleri dikkate alındığında, reel döviz kuru istikrarının sağlanması için yapısal ve kurumsal reformlar gerçekleştirilerek petrol ve doğalgaz hariç diğer endüstrilerin geliştirilmesinin sürdürmesi ve aynı zamanda Rusya, Türkmenistan, Azerbaycan gibi petrol ve doğalgaz bakımından zengin ülkelerle ticaret hacmini artırması önem taşımaktadır.

\section{Kaynaklar}

Ağayev, Seymur (2013). "Satın Alma Gücü Paritesi Hipotezinin Kazakistan İçin Geçerliliği". Uluslararası Avrasya Ekonomileri Konferansı. Kazan, Rusya 1718 Eylül. 272-379.

Ağazade, Seymur (2018) "Reel Döviz Kuru ve Petrol Fiyatları İlişkisinde Asimetri: Azerbaycan Örneğinde Bir İnceleme”. Uluslararası İktisadi ve İdari Incelemeler Dergisi 22: 113-126.

Aliev, Timur M. (2015). "Kazakhstan". Problems of Economic Transition 57 (10): $1-28$.

Amano, Robert A. ve Simon van Norden (1998a). "Exchange Rates and Oil Prices". Review of International Economics 6 (4): 683-694.

Amano, Robert A. ve Simon van Norden (1998b). "Oil Prices and the Rise and Fall of the US Real Exchange Rate". Journal of International Money and Finance 17 (2): 299-316.

Bal, Debi Prasad ve Badri Narayan Rath (2015). "Nonlinear Causality between Crude Oil Price ve Exchange Rate: A Comparative Study of China and India”. Energy Economics 51: 149-156.

BP (2016). "BP Statistical Review of World Energy June 2016". https://www. bp.com/content/dam/bp/pdf/energy-economics/statistical-review-2016/ bp-statistical-review-of-world-energy-2016-full-report.pdf (Erişim Tarihi: 02.12.2016).

Caprio, Jerry ve Peter B. Clark (1981). Oil Price Shocks in a Portfolio-balance Model. International Finance Discussion Papers Number 181.

Chaudhuri, Kausik ve Betty C. Daniel (1998). "Long-run Equilibrium Real 
Exchange Rates and Oil Prices”. Economics Letters 58 (2): 231-238.

Chen, Jen-Eem, Chin-Yu Lee ve Lim-Hhye Goh (2013). "Exchange Rate and Oil Price: Asymmetric Adjustment”. Applied Economics Letters 20 (10): 987-990.

Chen, Shiu-Sheng ve Hung-Chyn Chen (2007) "Oil Prices and Real Exchange Rates”. Energy Economics 29 (3): 390-404.

De Vita, Glauco ve Emmanouil Trachanas (2016). “'Nonlinear Causality between Crude Oil Price and Exchange Rate: A Comparative Study of China and India' - A Failed Replication (Negative Type 1 and Type 2)”. Energy Economics 56: 150-160.

Dickey, David A. ve Wayne A. Fuller (1981). "Likelihood Ratio Statistics for Autoregressive Time Series with a Unit Root". Econometrica 49 (4): 10571072.

Dünya Bankası (2016). World Bank. World Development Indicators. http:// databank.worldbank.org/data/reports.aspx?source=world-developmentindicators (Erişim Tarihi: 02.12.2016).

EBRD “Transition Indicators". http://www.ebrd.com/what-we-do/economicresearch-and-data/data/forecasts-macro-data-transition-indicators.html (Erişim Tarihi: 07.05.2017).

Engle, Robert F. ve C. W. J. Granger (1987). “Co-Integration and Error Correction: Representation, Estimation, and Testing”. Econometrica 55 (2): 251-276.

Golub, Stephen S. (1983). "Oil Prices and Exchange Rates". The Economic Journal 93 (371): 576-593.

Habib, Maurizio Michael ve Margarita Manolova Kalamova (2007). Are There Oil Currencies? The Real Exchange Rate of Oil Exporting Countries. ECB Working Paper Series No 839.

Hasanov, Fakhri (2010). The Impact of Real Oil Price on Real Effective Exchange Rate: The Case of Azerbaijan. DIW Berlin Discussion Paper No. 1041.

Huang, Ying ve Feng Guo (2007). "The Role of Oil Price Shocks on China's Real Exchange Rate". China Economic Review 18 (4): 403-416.

Ibadildin, Nygmet (2011). Role of the Old and New Institutional Framework in Combating the Resource Curse in Kazakhstan. Academic Dissertation University of Tampere School of Management, Finland.

Jahan-Parvar, Mohammad R. ve Hassan Mohammadi (2011). "Oil Prices and Real Exchange Rates in Oil-exporting Countries: A Bounds Testing Approach". The Journal of Developing Areas 45: 309-318.

Johansen, Soren ve Katarina Juselius (1990). "Maximum Likelihood Estimation and Inference on Cointegration with Applications to the Demand for Money". Oxford Bulletin of Economics and Statistics 52 (2): 169-210.

Koranchelian, Taline (2005). The Equilibrium Real Exchange Rate in a Commodity 
Exporting Country:Algeria's Experience. IMF Working Paper Series WP/05/135. Korhonen, Iikka ve Tuuli Juurikkala (2007). Equilibrium Exchange Rates in OilDependent Countries. BOFIT Discussion Paper No. 8/2007.

Krugman, Paul (1980). Oil and the dollar. NBER Working Paper No. 554.

Krugman, Paul (1983). Oil shocks and exchange rate dynamics. NBER Chapters in: Exchange Rates and International Macroeconomics: 259-284.

Kutan, Ali M. ve Michael L. Wyzan (2005). "Explaining the Real Exchange Rate in Kazakhstan, 1996-2003: Is Kazakhstan Vulnerable to the Dutch Disease?" Economic Systems 29 (2): 242-255.

KCS (2016). Ministry of National Economy of the Republic of Kazakhstan Committee on Statistics Express Information No: E-37-02/277. 29 July.

Kwiatkowski, Denis, Peter C.B. Phillips, Peter Schmidt ve Yongcheol Shin (1992). "Testing the Null Hypothesis of Stationarity against the Alternative of a Unit Root: How Sure Are We That Economic Time Series Have a Unit Root?". Journal of Econometrics 54 (1-3): 159-178.

NBK (1999). Правила Проведения Конвертации Тенговых Депозитов Физических И Юридических Лиц В Банках Второго Уровня В Связи С Переходом К Режиму Свободно Плавающего Обменного Курса Тенге. Правила Национального Банка от 05.04. N 62.

NBK (2004). National Bank of Kazakhstan Press Release No: 20. September 14, 2004. NBK (2009). National Bank of Kazakhstan Press Release No: 3. February 4, 2009. NBK (2014). National Bank of Kazakhstan Press Release No: 5. February 11, 2014. NBK (2015a). National Bank of Kazakhstan Press Release No: 33. July 15, 2015. NBK (2015b). National Bank of Kazakhstan Press Release No: 38. August 21, 2015.

Nikbakht, Leili (2010). "Oil Prices and Exchange Rates: The Case of OPEC". Business Intelligence Journal 3: 83-92.

Oskenbayev, Yessengali ve Aziz Karimov (2013). Is Kazakhstan Vulnerable to Natural Resource Curse? WIDER Working Paper No 2013/130.

Oskenbayev, Yessengali (2015). International Analyses of Natural Resource Curse and Kazakhstan's Related Economic Performance with Special Attention to Its Wheat and Energy Sectors. Doctoral Thesis. Germany: University of Bonn.

Pesaran, M. Hashem, Yongcheol Shin ve Richard J. Smith (2001). "Bounds Testing Approaches to the Analysis of Level Relationships". Journal of Applied Econometrics 16 (3): 289-326.

Phillips, Peter C. B. ve Pierre Perron (1988). “Testing for a Unit Root in Time Series Regression". Biometrica 75 (2): 335-346.

Rautava, Jouko (2004). "The Role of Oil Prices and The Real Exchange Rate in Russia's Economy-A Cointegration Approach". Journal of Comparative 
Economics 32 (2): 315-327.

Sachs, Jeffrey D. ve Andrew M. Warner (2001). Natural Resource Abundance and Economic Growth. NBER Working Papers 5398.

Togay, Selahattin (2009). "Kazakistan Ekonomisinin Petrole Bağımlılığının Azaltılmasında Para Politikasının Rolü”. bilig, Türk Dünyası Sosyal Bilimler Dergisi 48: 207-240.

Turhan İbrahim, Erk Hacihasanoglu ve Uğur Soytas (2013). "Oil Prices and Emerging Market Exchange Rates". Emerging Markets Finance and Trade 49 (1): 21-36.

UNCTAD. United Nations Conference on Trade and Development. Data Center. "Product Concentration and Diversification Indices by Economy". http:// unctadstat.unctad.org/wds/TableViewer/tableView.aspx?ReportId=120 (Erişim Tarihi: 05.07.2017).

Zalduendo, Juan (2006). Determinants of Venezuela's Equilibrium Real Exchange Rate. IMF Working Paper Series WP/06/74.

Zhang, Yue-Jun, Ying Fan, Hsien-Tang Tsai ve Yi-Ming Wei (2008). "Spillover Effect of US Dollar Exchange Rate on Oil Prices”. Journal of Policy Modeling 30 (6): 973-991.

Zhang, Yi (2013). "The Links between the Price of Oil and the Value of US Dollar". International Journal of Energy Economics and Policy 3 (4): 341-351.

Wang, Yudong ve Chongfeng Wu (2012). "Energy Prices and Exchange Rates of the U.S. Dollar: Further Evidence from Linear and Nonlinear Causality Analysis". Economic Modelling 29: 2289-2297.

WEF. World Economic Forum. "Global Competitiveness Index". http:// www3.weforum.org/docs/GCR2016-2017/06Othershareables/GCI_ Dataset_2006-2016.xlsx (Erişim Tarihi: 07.05.2017) 


\title{
Oil Prices and Kazakhstan's Real Exchange Rate: An ARDL Bound Test Approach*
}

\section{Seymur Ağazade**}

\begin{abstract}
Using different real exchange rate indexes and bound test approach, this paper investigates the effect of real oil prices on Kazakhstan's real exchange rate. Results of long run ARDL approach show that increases in real oil prices causes appreciation of real effective exchange rate index which includes all trading partners of Kazakhstan or the countries outside of CIS, but causes depreciation in real effective exchange rate index which includes only CIS countries. Alongside this, ARDL error correction model shows that deviation from long run relationship is corrected in a shorter span of time when real effective exchange rate index which includes CIS countries is taken into account. The results indicate that in order to ensuring real exchange rate stability, it is important to maintain the development of other sectors together with rapid growing oil and gas sectors and to increase trade with oil rich neighbouring countries.
\end{abstract}

\section{Keywords}

Oil prices, real exchange rate, bound test, ARDL approach, Kazakhstan.

Date of Arrival: 15 January 2017 - Date of Acceptance: 26 June 2018

You can refer to this article as follows:

Ağazade, Seymur (2020). "Petrol Fiyatları ve Kazakistan Reel Döviz Kuru: ARDL Sınır Testi Yaklaşımı”. bilig - Journal of Social Sciences of the Turkic World 94: 217-248.

* Prof. Dr., Alanya Alaaddin Keykubat University, Tourism Faculty, Department of Tourism Management - Antalya/Turkey ORCID ID: 0000-0001-5484-5189

seymur.agazade@alanya.edu.tr 


\title{
Цены на нефть и реальный обменный курс Казахстана: подход с использованием предельного теста ARDL*
}

\section{Сеймур Агазаде}

\begin{abstract}
Аннотация
В данной статье исследуется влияние реальных цен на нефть на реальный обменный курс Казахстана, используются различные индексы реального обменного курса и подход с использованием предельного теста (bound test). Результаты теста ARDL показывают, что повышение реальных цен на нефть вызывает повышение индекса реального эффективного обменного курса, который включает в себя всех торговых партнеров Казахстана или стран за пределами СНГ, но вызывает снижение индекса реального эффективного обменного курса, который включает только страны СНГ. Наряду с этим модель исправления ошибок ARDL показывает, что отклонение от долгосрочных отношений корректируется за более короткий промежуток времени, когда учитывается индекс реального эффективного обменного курса, который включает страны СНГ. Результаты показывают, что для обеспечения стабильности реального обменного курса важно поддерживать развитие других секторов наряду с быстро растущими нефтегазовыми секторами и расширять торговлю с богатыми нефтью соседними странами. Ключевые слова
\end{abstract}

Цены на нефть, реальный обменный курс, предельный тест, подход ARDL, Казахстан.

\footnotetext{
“ Поступило в редакцию: 15 января 2017 г. - Принято в номер: 26 июня 2018 г. Ссылка на статью:

Ağazade, Seymur (2020). "Petrol Fiyatları ve Kazakistan Reel Döviz Kuru: ARDL Sınır Testi Yaklaşımı". bilig - Журнал Гуманитарных Наук Тюркского Мира 94: 217-248.

** Проф., д-р, Университет Аланья Алааддина Кейкубад, Факультет туризма, Управление туризмом - Анталья/Турция ORCID ID: 0000-0001-5484-5189 seymur.agazade@alanya.edu.tr
} 